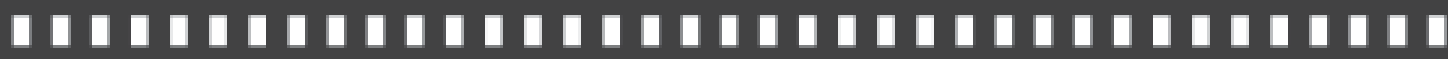 Por um fotojornalismo que respeite a dignidade humana: a dimensão ética como questão fundamental na contemporaneidade

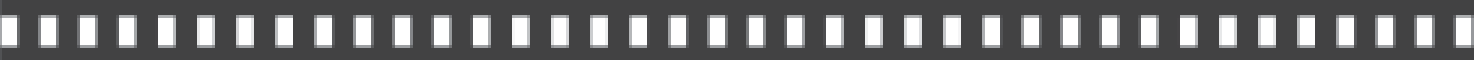

\author{
Janaina Dias Barcelos
}

Artigo recebido em: 04/02/2013

Artigo aprovado em: 08/07/2013 


\title{
Por um fotojornalismo que respeite a dignidade humana: a dimensão ética como questão fundamental na contemporaneidade
}

\author{
For a photojournalism that respects the human dignity: the ethical dimension \\ as a key issue in contemporaneity
}

\author{
Janaina Dias Barcelos *
}

\begin{abstract}
Resumo: Este trabalho propõe discutir sobre os limites éticos do uso pela imprensa de fotos que retratam dor e sofrimento humanos. $O$ objetivo é refletir sobre o papel do fotojornalismo e o respeito à dignidade humana. Buscamos comparar cinco documentos, verificando similaridades e diferenças, e exemplificamos algumas discussões com fotografias selecionadas a partir de seu alcance e sua noticiabilidade. Buscamos aporte teórico em autores que abordam a dimensão ética do jornalismo, bem como naqueles que estudam ofotojornalismo. Em nossa análise, percebemos que existem orientações para os profissionais, voltadas ao respeito à dignidade humana, mas que ainda há um longo caminho a ser percorrido para que a mídia impressa cumpra esse papel social.
\end{abstract}

Palavras-chave: Fotojornalismo. Ética. Deontologia. Imagem.

\begin{abstract}
This paper proposes to discuss the ethical limits of the use by the press of photos portraying human pain and suffering. The aim is to reflect on the role of photojournalism and respect to human dignity. We compare five documents verifying similarities and differences, and exemplify some discussions with photos chosen by its scope and newsworthiness. The theoretical approach considers authors who address the ethical dimension of journalism, as well as those who research the photojournalism. In our analysis, we verified that there are guidelines for professionals, dedicated to respect for human dignity, but there is still a long way to go for that press media fully accomplishes such social role.
\end{abstract}

Keywords: Photojournalism. Ethics. Deontology. Image.

* Doutoranda do Programa de Pós-Graduação em Estudos Linguísticos da FALE/UFMG. Mestre em Comunicação e Jornalismo pela Universidade de Coimbra. Especialista em Comunicação e Gestão Empresarial pela PUC/Minas. Graduada em Comunicação Social - Jornalismo pela UFMG. E-mail: janabarcelos@hotmail.com 


\section{Introdução}

Desde a descoberta da fotografia e a realização dos primeiros retratos até a oferta de máquinas digitais de fácil operação que permitem a qualquer cidadão registrar o que ocorre à sua volta, muito tempo se passou. Assistimos a vários avanços na técnica, mas uma questão continua fundamental na contemporaneidade: a ética. Sob esse aspecto, seja de que forma a imagem for produzida ou veiculada, continua a ser essencial refletir sobre como se deve mostrar os acontecimentos registrados pelas lentes das câmeras fotográficas, se há limites sobre o que e como exibir. Será que a comunicação tende a permanecer no terreno da espetacularização ou haveria espaço para a construção de propostas que considerem o respeito à dignidade do ser humano em primeiro lugar? ${ }^{1}$

Esse cuidado com a produção e a seleção ganha dimensão muito maior e relevante quando as imagens são produzidas para a imprensa, seja por repórteres fotográficos ou por fotojornalistas ${ }^{2}$. Isso porque a prática do jornalismo carrega consigo uma função social, ligada ao exercício da cidadania, à liberdade de expressão e ao direito à informação, aspectos que podem entrar em choque em alguns momentos. Além disso, o exercício profissional pressupõe regras de conduta da atividade, geralmente descritas em códigos de ética ou deontológicos. Esses modos de agir também podem ser expressos e mesmo definidos por meio da partilha da cultura profissional, dentro do que Traquina (2004) nomeia como comunidade interpretativa transnacional ou tribo. Assim, as interações entre o grupo profissional contribuiriam para definir papéis, grupos de referência, padrões

1 Este artigo é uma compilação de alguns capítulos da dissertação de mestrado da autora, apresentada à Universidade de Coimbra, Portugal, em dezembro de 2009, com o título "Fotojornalismo: dor e sofrimento. Estudo de caso do World Press Photo of the Year 1955-2008".

2 Mesmo quando os veículos de comunicação recebem imagens produzidas por cidadãos que registram determinado acontecimento com suas câmeras digitais ou pelo celular, a responsabilidade do jornalista permanece, pois será ele, seja como editor, diretor, produtor etc., que irá selecionar a imagem a ser veiculada e de que forma isso ocorrerá. Sobre a produção das imagens, independentemente de serem feitas por repórteres fotográficos que passaram por gradução em Jornalismo ou por fotojornalistas formados pela prática e pela experiência, defendemos que eles partilham valores e condutas profissionais que interferem nas escolhas éticas. 
de ação e estilos de pensamento, que ajudariam a organizar o discurso visual.

Nossa proposta, neste trabalho, é discutir os limites éticos no campo profissional do fotojornalismo, principalmente quando a imagem retrata dor e sofrimento. A finalidade é fazer isso sob a perspectiva de cinco códigos de ética ou deontológicos, que serão analisados e exemplificados, a fim de verificarmos se determinadas imagens estariam ou não em conformidade com o que recomenda tais documentos. Selecionamos o Código de Ética dos Jornalistas Brasileiros; o Código Deontológico dos Jornalistas portugueses; a Declaração dos Direitos e Deveres dos Jornalistas, conhecida como Carta de Munique; o Código de Ética da Associação Nacional de Fotógrafos de Imprensa (NPPA) e os Princípios Internacionais de Ética Profissional, elaborados com apoio da Unesco. ${ }^{3}$

Consideramos esse critério de análise pertinente, a partir do pressuposto de Sousa (2004a), de que a cultura e as convenções profissionais do fotojornalismo são, em larga escala, transorganizacionais e transnacionais. Logo, poderemos perceber regularidades e diferenças entre as orientações de cada documento, que foram selecionados de forma a contemplar dois códigos de países de língua portuguesa, um que orienta a comunidade europeia, um que teria abrangência internacional e outro especificamente voltado para a imagem, permitindo-nos ampliar o alcance de nossa percepção e de contemplar a noção de comunidade interpretativa transnacional.

Como exemplo dessa "unidade", Sousa (2004a, p.130) cita um dos principais concursos de fotografia, o World Press Photo, que premia, na grande maioria dos casos, imagens relacionadas à violência: "A similaridade das 'fotos do ano', pelo menos temática, mas também nos conteúdos [...], poderá ser um traço de transnacionalização do fotojornalismo e de sua transculturalização, até porque as fotos são realizadas por fotógrafos de vários países". A primazia conferida a

Versão original: Declaration of the Rights and Duties of Journalists; National Press Photographers Association (NPPA); e International Principles of Professional Ethics in Journalism. 
fotografias que retratam dor e sofrimento, entre as vencedoras da categoria Foto do Ano do World Press Photo, também foi verificada por Barcelos (2009). O estudo revelou que 88,2\% das imagens vencedoras, entre 1955 e 2008, apresentam situações dolorosas. Para este trabalho, a seleção das fotografias que exemplificam a discussão seguiu os critérios de alcance e noticiabilidade: buscamos imagens conhecidas e bastante divulgadas, muitas, inclusive, tendo gerado polêmicas devido à exposição de situações que envolviam dore sofrimento.

\section{Os limites éticos por trás do click}

Muitas fotografias que retratam dor e sofrimento do outro foram realizadas por fotógrafos de renome, desde Lewis Hine, no século XIX, até Sebastião Salgado, na atualidade, e constituíram-se ícones do fotojornalismo mundial. Sabemos que a forma e a velocidade com que essas imagens passaram a chegar ao público submetem-se a rotinas produtivas que sofrem várias interferências, passando pela noticiabilidade de conflitos bélicos, catástrofes e problemas sociais, pelo surgimento de novas tecnologias e pelo enorme desenvolvimento dos meios de comunicação de massa, que se concentraram e internacionalizaram.

No entanto, tais constrangimentos e circunstâncias podem não justificar escolhas que firam a dignidade do ser humano em momentos de dor. Um dos princípios básicos de defesa dos direitos fundamentais do homem é o respeito à sua dignidade, cuja proteção e promoção representam direito constitucional nas sociedades democráticas. Inicialmente concebida no plano filosófico, a ideia de dignidade consagrouse como valor moral e, posteriormente, jurídico. Na antiguidade clássica, já se discutia que o ser humano possui uma qualidade que o distingue de outras criaturas e que independe de diferenças sociais, culturais ou individuais.

O pensamento moderno, cujas noções de liberdade e igualdade moveram a Revolução Francesa, também adota a concepção de que a 
sociedade ideal deveria ser organizada visando à felicidade humana e só poderia nascer do respeito aos direitos naturais do homem. Adignidade seria a base da liberdade humana. Portanto, esse respeito precisaria ser levado em consideração ao produzir e selecionar, para ir a público, imagens que retratam a dor e o sofrimento do outro, ao observar que "o único limite à liberdade individual é o dano aos demais"4 (CAMPS, 2004, p.34). Isso significa que a liberdade de expressão existe numa relação com o outro.

Como há raros códigos de ética específicos para fotógrafos (salvo em algumas grandes agências ou associações), optamos por elaborar a análise com base em códigos voltados para jornalistas, já que o antigamente nomeado fotógrafo de imprensa conquistou o estatuto de repórter fotográfico (também chamado fotojornalista) ${ }^{5}$. Além disso, o processo de escolha das imagens pela imprensa passa por outros profissionais do jornalismo, como o editor e o diretor de redação, por exemplo.

Acreditamos ser relevante promover esse tipo de análise e incentivar o debate, pois é fundamental discutir sobre como devem ser realizadas, selecionadas e publicadas imagens de acontecimentos que envolvem a dor do outro. Recorremos a uma citação que resume muito bem essa reflexão e indica que existiria um caminho que pressupõe uma escolha:

\begin{abstract}
Existem diversas maneiras de falar do outro: entre a conivência e a cumplicidade, que leva a desnaturar toda ou parte da realidade, e a arrogância, o desprezo ou a indiferença, que magoam, estendese uma zona muito vasta onde a atenção, a precisão, o rigor na procura e na relação dos factos em nada são incompatíveis com essa faculdade de solicitude, que traduz uma estima pelo outro que tem muito de estima de si. (CORNU, 1994, p.406).
\end{abstract}

Sabemos que a liberdade de imprensa é instrumento essencial para o funcionamento da democracia, mediante a qual os cidadãos exercem

\footnotetext{
4 Versão original: "el único limite a la libertad individual es el daño a los demás".

5 Não pretendemos entrar no mérito das definições das categorias profissionais, se o fotógrafo passou ou não por formação acadêmica em Jornalismo, pois defendemos que eles partilham condutas profissionais semelhantes, como já explicamos anteriormente no texto.
} 
seu direito de receber, divulgar e buscar informação. Liberdade que promove o livre debate de ideias e opiniões, fundamental para a consolidação e o desenvolvimento democráticos. Entretanto, apesar de ser um direito individual, a liberdade só tem sentido se em relação direta com um espaço público, uma vez que se configura também um valor comum, inscreve-se num contexto, num tempo e num lugar. Por isso, é preciso se ter claro que:

Entre a reivindicação de um direito à informação [...] e a renúncia a métodos que ofendem ao mesmo tempo a deontologia como regulação e o respeito pela pessoa como objeto ético, deve privilegiar-se claramente a segunda. A liberdade de imprensa e o dever de informação do público não autorizam tudo. (CORNU, 1994, p.83).

Para Gozálvez (2004b), valores como igualdade (dignidade e respeito), liberdade (juntamente com independência, participação, autonomia e desenvolvimento humano), pluralidade, civismo (solidariedade e paz) e autorrealização (felicidade e vida plena) deveriam nortear a atividade jornalística. $\mathrm{O}$ autor ressalta que, se a imprensa utilizar essas medidas em mensagens, ideias e imagens que faz circular, irá comunicar uma visão do outro e do semelhante que poderá contribuir para a luta por visibilidade de grupos ou povos silenciados, bem como aproximar mensagens simbólicas de vozes fisicamente distantes com base em princípios que ajudam a construir um mundo mais justo.

Percebemos que existem fotografias de dor e sofrimento que são canalizadoras de mobilização da opinião pública e de transformações sociais. Outras apelam para a estética do horror e para o choque. A questão é que a ideia corrente de que é preciso apresentar a realidade de forma crua e violenta para criar sensações e de que a sociedade deve estar bem informada faz com que, a cada dia, se respeite menos os direitos humanos e se perca o sentido de intimidade. Essa realidade é apontada por Cornu (1994), ao abordar a responsabilidade do jornalismo para com o público: 
Os relatos de catástrofes naturais, de conflitos bélicos, de acidentes espectaculares espezinham o mais das vezes esta forma de respeito ao outro, explorando-os sem vergonha para fins comerciais, numa "impiedosa caça ao sofrimento humano" (Pürer) e com o pretexto de dar ao acontecimento o seu human touch. É um domínio onde a deontologia profissional tem ainda um imenso caminho a percorrer: parece que quanto mais os media se desenvolvem mais este tende a alongar-se, sob a influência do espectacular a qualquer preço, da regra do "peso das palavras" e do 'choque das fotos', que varre na sua passagem todo o pudor e toda a compaixão. (CORNU, 1994, p.99).

Por isso, normas éticas e deontológicas são necessárias. Elas contribuem para evitar o abuso, para orientar e conscientizar os profissionais. Como aponta San Martin (1996), fundamentos éticos ajudam na tomada de decisões sobre quais fotografias publicar ou não, se elas têm conteúdo informativo, servem para educar ou complementar a informação apresentada. Ponto de vista reforçado por Camps (2004, p.41), para quem "a ética consiste nisso: na projeção de uma série de 'ideias reguladoras' da prática, as quais nos servem tanto para indicar critérios de ação, como para avaliar as distintas práticas"'. Entretanto, além de códigos, espera-se do profissional motivação, criatividade, formação sólida, preocupação cultural e intelectual, investigação e sentido de responsabilidade, como enumera San Martin (1996).

Ao mesmo tempo em que é necessário preservar o direito das pessoas às informações, no caso, transmitidas pelos meios de comunicação, é fundamental a responsabilidade de exercer o fotojornalismo dentro de um marco deontológico que estabeleça a linha divisória entre fotografias que respeitam o bem comum e aquelas ofensivas aos valores do ser humano. Afinal, "O direito à informação só se sustenta se essa informação servir ao cidadão para a produção de conhecimento" (CAMPS, 2004, p.48).

6 Versão original: "la ética consiste en eso: en la proyección de una serie de 'ideas reguladoras' de la practica, las cuales nos sirven tanto para señalar critérios de acción, como para evaluar las distintas practicas".

7 Versão original: "El derecho a la informacción solo se sustenta si esa informacción ha de servirle al ciudadano para la producción de conocimento". 


\section{Do papel à prática}

Esclarecemos que nossa análise foca nos artigos dos códigos que se referem, direta ou indiretamente, à questão da dignidade humana e à postura diante de situações delicadas, como as que envolvem dor e sofrimento. A partir desse método, percebemos que o Código de Ética dos Jornalistas Brasileiros (FEDERAÇÃO NACIONAL DOS JORNALISTAS, 2007) é explícito ao determinar, no Artigo $9^{\circ}$, que é dever do profissional: "Divulgar todos os fatos que sejam de interesse público", e ainda "Opor-se ao arbítrio, ao autoritarismo e à opressão, bem como defender os princípios expressos na Declaração Universal dos Direitos do Homem". Dessa forma, em primeiro lugar, o documento indica que as pessoas têm direito de saber o que acontece no mundo, sendo os acontecimentos caracterizados como dolorosos ou não. Em segundo lugar, essa informação deveria ser passada de forma a contribuir para a defesa dos Direitos Humanos, logo, a respeitar a dignidade.

Portanto, as fotografias precisariam também levar esse aspecto em consideração: se os sujeitos retratados têm sua dignidade preservada. Mas como medir isso? Além do bom senso, da consciência e da sensibilidade do profissional, uma maneira de verificar isso seria analisar se a imagem "coisifica" a pessoa, ou seja, se aquela informação é essencialmente necessária para a compreensão de dada realidade ou se o ser humano retratado serve apenas como instrumento, seja para chocar, causar piedade, aumentar a audiência, ou qual for o objetivo do fotógrafo ou do veículo de comunicação. O cuidado deve ser total, considerando que atrocidades muitas vezes destroem "o que identifica as pessoas como indivíduos, até como seres humanos" (SONTAG, 2003, p.67). Explorar tal circunstância seria ir contra o que diz o Artigo $14^{\circ}$ que aponta como dever "Tratar com respeito a todas as pessoas mencionadas nas informações que divulgar", e, aqui, sentimo-nos no direito de substituir: seria dever do fotojornalista tratar com respeito todas as pessoas retratadas nas fotografias que divulgar. 
O que, sob nosso ponto de vista, não aconteceria na fotografia realizada por James Nachtwey de uma vítima de fome num campo de alimentação do Sudão, em 1993 (Figura 1). O sujeito é retratado como um animal, nu, esquelético, posicionado de quatro. Tal estética do horror e do choque não respeitaria o que diz o código acima, muito menos o que propõe a filosofia kantiana. De acordo com ela, o homem é um ser racional, que existe como um fim e não como um meio, portanto, tem um valor próprio que não pode ser apreçado ou substituído. Dessa forma, podemos dizer que a proteção e promoção da dignidade do ser humano representariam uma necessidade material e uma condição para a construção e para o desenvolvimento da própria humanidade.

Figura 1 - "Sudan, 1993 - Famine victim in a feeding center"

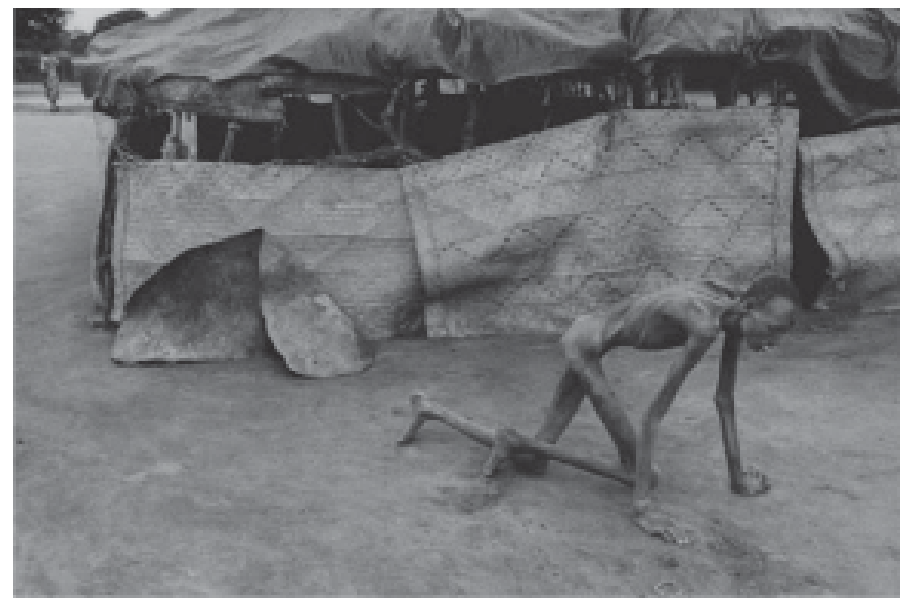

Fotografia: James Nachtwey

Fonte: Sudan ... (1993)

O interessante é que a produção de Nachtwey contempla tanto fotos-choque quanto imagens de um lirismo e uma sensibilidade impressionantes, como é o caso da fotografia "Mãe e filho" (Figura 2), também realizada no Sudão, que retrata uma mãe cuidando do filho no leito, numa referência à Pietá, de Michelangelo. Ambas as fotografias revelam situações de dor e sofrimento, o que indica que o "como" mostrar também faz parte das escolhas do fotógrafo. 
Figura 2 - "Mother and Son", 2004

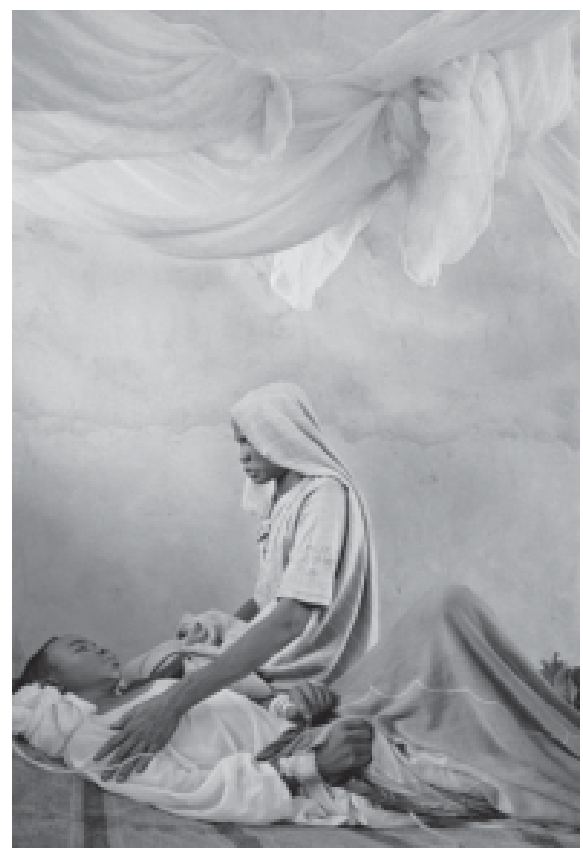

Fotografia: James Nachtwey.

Foto vencedora, em 2004, da categoria Contemporary Issues, do World Press Photo

Fonte: Mother...(2004)

Outra recomendação do código brasileiro, presente no Artigo $9^{\circ}$, é "Respeitar o direito à privacidade do cidadão", ou seja, tanto da pessoa que aparece na fotografia quanto a de seus familiares. Daí tantas controvérsias diante de imagens que mostram rostos de mortos, ou vítimas de catástrofes. Primeiramente, seria aconselhável que essas pessoas (ou familiares) autorizassem a divulgação da imagem. Mas, avaliamos que não haveria razão para exibir as faces dessas pessoas, pois isso significaria expô-las sem necessidade. Que informação útil pode obter o leitor ao contemplar o rosto de um cadáver? Onde está o interesse público? Mas qual o peso dessa publicização da dor para um familiar? Além disso, o Artigo $13^{\circ}$ afirma que o jornalista deve evitar a divulgação de fatos "de caráter mórbido e contrários aos valores humanos". Há, ainda, o aspecto legal: 
O direito positivo não proíbe só a captação ou reprodução de imagens do corpo com vida, como também, e talvez por duplo motivo já que afeta também o direito à intimidade, as imagens de uma pessoa obtidas durante sua agonia ou as imagens de um corpo inerte, ou seja, de seu cadáver. ${ }^{8}$ (JARA apud SAN MARTIN, 1996, p.15)

Isso significa que a reprodução desse tipo de fotografia violaria o direito legal e ético, pois se refere a algo íntimo e pessoal como o direito de ter uma morte digna e privada.

Exemplo clássico do não atendimento aos critérios apontados acima foi a divulgação das imagens dos cadáveres dos filhos de Saddam Hussein, pelas forças militares norte-americanas, em 2003 (Figura 3), e do enforcamento do próprio ditador iraquiano e sua publicização em 2006, seja em meios impressos ou eletrônicos ${ }^{10}$.

\section{Figura 3 - Cadáver de um dos filhos de Saddam Hussein}

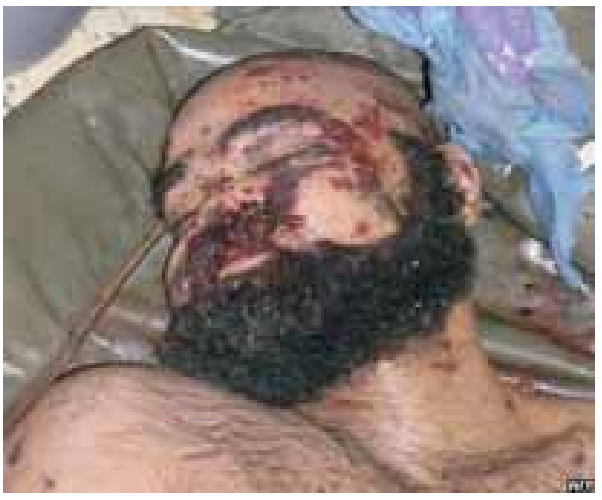

Fotografia: AFP

Fonte: Cadáver... (2014)

8 Versão original:“El derecho positivo no prohíbe sólo la captación o reproducción de imágenes del cuerpo com vida, sino también, y tal vez por doble motivo en cuanto que afecta también al derecho a la intimidad, a las imágenes de una persona obtenidas durante su agonia o las imágenes de un cuerpo inerte, es decir de su cadáver".

9 San Martin cita Royo Jara, autor de "La protección de derecho a la propia imagen".

${ }^{10}$ A facilidade de se divulgar imagens na Web e a rapidez com que circulam no mundo todo - e que favoreceu a divulgação e rápida disseminação das fotos mencionadas - é outro ponto que merece estudos, mas não constitui foco deste trabalho. 
Os princípios do Código Deontológico dos Jornalistas, em Portugal ${ }^{11}$ estão em sintonia com o Código brasileiro. O item 7 assinala que o jornalista (e por conseguinte o fotojornalista) "deve proibir-se de humilhar as pessoas ou perturbar a sua dor". Em relação à privacidade, o Código português abre exceções e é mais detalhado que o brasileiro. Está expresso no item 9:

O jornalista deve respeitar a privacidade dos cidadãos excepto quando estiver em causa o interesse público ou a conduta do indivíduo contradiga, manifestamente, valores e princípios que publicamente defende. O jornalista obriga-se, antes de recolher declarações e imagens, a atender às condições de serenidade, liberdade e responsabilidade das pessoas envolvidas. (CÓDIGO, 1993).

A Declaração dos Direitos e Deveres dos Jornalistas, ou Carta de Munique $^{12}$, também trata da privacidade, no item 5, mas de maneira breve e direta, como no Código brasileiro: "Sentir-se obrigado a respeitar a vida privada das pessoas"13. No mais, aborda o mesmo que a maioria dos códigos, como garantir a correção, precisão e certeza da informação divulgada, não aceitar pressões, defender a liberdade de informação e opinião, respeitar a verdade e preservar as fontes. Não menciona aspectos específicos de uso de imagens (a não ser o item 4 que condena o uso de métodos desleais para obter informações, fotos ou documentos).

Para Camps (2004, p.34), nesses contextos de exposição da dor, o direito à privacidade e à própria imagem precisa ser resguardado e "Efetivamente, tanto a intimidade e a honra das pessoas como a obrigação de proteger os mais vulneráveis constituem as duas fronteiras mais explícitas à liberdade de expressão e de informação" ${ }^{14}$. Nesse sentido, seria preciso

${ }^{11}$ SINDICATO DOS JORNALISTAS. Código deontológico dos jornalistas. 1993. Disponível em: <http://www.jornalistas.eu/?n=24>. Acesso em abr. 2014.

12 DECLARATION of the Rights and Duties of Journalists, Charter of Munich. Munich, 1971. Disponível em: <http://www.hirondelle.org/wp-content/uploads/2011/07/Declaration-of-TheRights-and-Duties-Of-Journalists-Charter-of-Munich-1971.pdf>. Acesso em: abr. 2014.

${ }^{13}$ Versão original: "Feeling obliged to respect the private life of people".

14 Versão original: "Efectivamente, tanto la intimidad y el honor de las personas como la obrigación de proteger a los más vulnerabeles constituyen las dos fronteras más explícitas a la libertad de expresión y de información". 
atentar para os limites, ainda que tênues, entre a liberdade de expressão e o direito à informação.

Já a declaração com os Princípios Internacionais de Ética Profissional dos Jornalistas ${ }^{15}$, apoiada pela Unesco, consiste em um documento internacional, que representa em torno de $400 \mathrm{mil}$ profissionais, sendo, portanto, bem abrangente. O segundo princípio é interessante e vale a pena ser analisado. Refere-se à "dedicação do jornalista à realidade objetiva" ${ }^{16} \mathrm{e}$ assinala que o jornalista está a serviço do direito das pessoas à informação verdadeira e autêntica. Para isso, deve reportar os fatos conscientemente, em seu devido contexto, apontando conexões e causas, para que o público possa ter material adequado que facilite sua formação e compreensão do mundo. Direcionando tal recomendação aos fotojornalistas, ressaltamos o que Sontag (2003,p.29) diz sobre as imagens: "A fotografia morde mais fundo. A memória congela as imagens". A partir da força moral que uma imagem pode ter e dos sentimentos que pode provocar, atenta-se para a importância que ela adquire para que o observador conheça e compreenda determinada realidade.

Para exemplificar esse item, resgatamos o episódio, em 2004, em que foram divulgadas internacionalmente imagens de presos iraquianos abusados e humilhados por soldados norte-americanos (Figura 4). A imagem fere a dignidade do sujeito ao retratá-lo sob condição humilhante, submissa. Sob esse aspecto, ela não deveria ter sido usada pela imprensa. Por outro lado, se as imagens não viessem à tona, tais atrocidades poderiam continuar acontecendo. $\mathrm{O}$ fato de as pessoas conhecerem tal realidade permite a mobilização da opinião pública, bem como a tomada de atitudes políticas e jurídicas, como de fato ocorreu.

\footnotetext{
${ }_{15}$ Participaram do encontro de organizações de jornalistas profissionais, com apoio da Unesco: International Organization of Journalists (IOJ), International Federation of Journalists (IFJ), International Catholic Union of the Press (UCIP), Federación Latinoamericana de Periodistas (FELAP), Federación Latino-Americana de los Trabajadores de la Prensa (FELATRAP), Federation of Arab Journalists (FAJ), Union of African Journalists (UAJ) e Confederation of Asean Journalists (CAJ). A IFJ não participou da reunião final em 20 de novembro de 1983, em Paris, quando o documento foi elaborado.

16 Versão original: "The journalist's dedication to objective reality".
} 
Figura 4 - Balada em Abu Ghraib

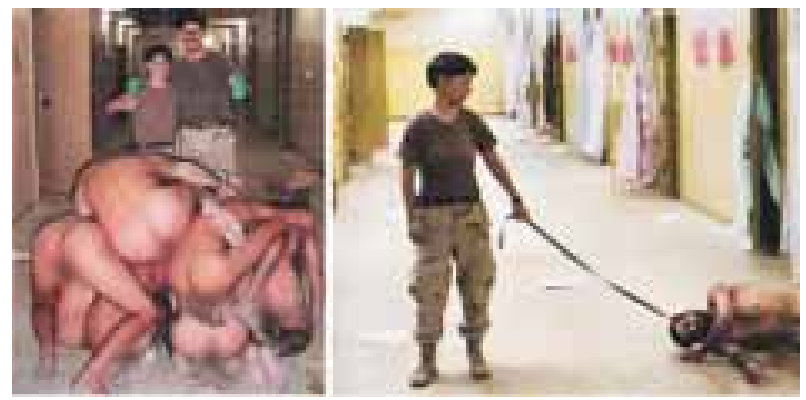

Fotografias: Reuters

Fonte: Balada... (2004)

O terceiro princípio toca em um ponto-chave da discussão: a responsabilidade social do (foto)jornalista, que deve agir em conformidade com uma consciência ética pessoal. $\mathrm{O}$ enunciado pode parecer perfeito, mas não aponta concretamente que tipo de atitude deveria ser adotado e em qual circunstância.

O respeito à privacidade e à dignidade humana é o tema do sexto princípio, considerado parte fundamental das normas profissionais, em conformidade com o previsto em leis nacionais e internacionais referentes à proteção dos direitos e da reputação dos outros. Será que, se esses códigos existissem há mais tempo ${ }^{17}$, a fotografia da queda de uma mulher e uma criança de uma escada de incêndio que se partiu durante o resgate, tirada por Stanley Forman em 1975 (Figura 5), teria ou não sido divulgada?

Forman contou que apontava a máquina para fotografar o resgate da mulher e da criança pelos bombeiros, quando a escada de incêndio se partiu. Depois de registrar, virou-se para não ver as duas no chão. Só soube que havia registrado exatamente o momento da queda quando revelou o filme ${ }^{18}$. A imagem foi publicada no Boston Herald e depois em jornais em todo o mundo, gerando debates sobre a divulgação de uma cena tão horrível. Stanley disse não ter se incomodado com a controvérsia

${ }^{17}$ Apenas a Munich Declaration of the Rights and Duties of Journalists existe desde 1971. Os outros documentos são de datas posteriores à foto de Forman.

${ }^{18} \mathrm{O}$ depoimento do fotógrafo pode ser verificado em matéria disponível no link <http:// www.bbc.co.uk/portuguese/reporterbbc/story/2005/10/printable/051005_worldpress $1975 \mathrm{cl} . \mathrm{shtml}>$ 
e que acredita ter feito a coisa certa, pois a fotografia serviu para fazer com que as pessoas saíssem de casa e checassem as escadas de incêndio, além de reivindicar mudanças na lei. Ela também foi usada em panfletos sobre segurança em caso de fogo por muitos anos.

Figura 5 - "Diana Bryant and Tiare Jones fall from the collapsing fire escape"

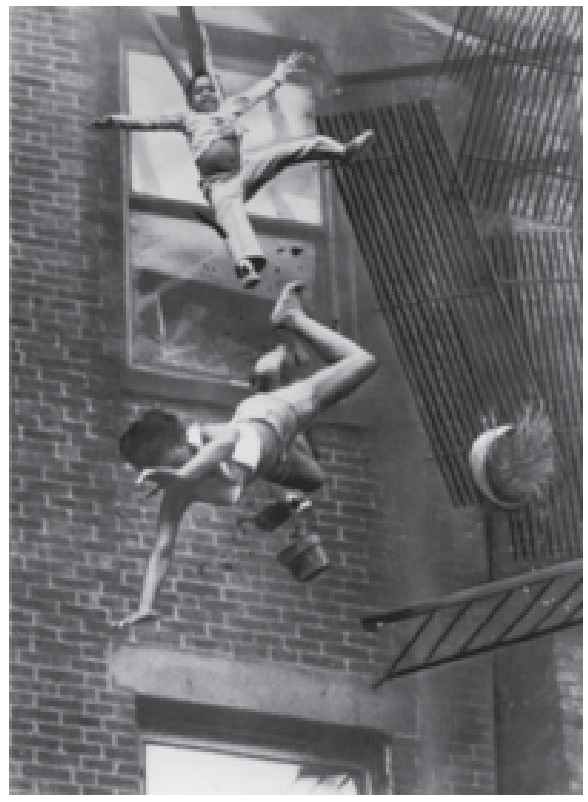

Fotografia: Stanley Forman

Fonte: Fire... (2014)

Já o princípio VIII do documento da Unesco discorre sobre uma série de atitudes e responsabilidades que pertencem à ética profissional, como orientar-se por valores universais de humanismo, paz, democracia, direitos humanos, respeitando os valores e a dignidade de cada cultura, bem como a liberdade de cada pessoa. O princípio IX reforça esse comprometimento ético com valores universais e aponta que o (foto)jornalista não pode contribuir para justificar ou incitar qualquer tipo de violência (guerra, racismo, opressão, pobreza, doenças etc.). Segundo o documento, ele deve ajudar as pessoas a entenderem as necessidades e 
os desejos do outro e a sensibilizarem-se, aumentando o respeito pelos direitos e pela dignidade de todos os povos.

Em relação a tal aspecto, podemos refletir sobre fotografias que mostram a condição degradante de determinados povos, em situação de pobreza, fome e miséria, ou seja, em sofrimento. Seria possível fazer essa realidade chegar às pessoas e, ao mesmo tempo, respeitar os sujeitos fotografados? Acreditamos que sim, mas atentando para o cuidado de não usar a fotografia como uma prática de "exibir seres humanos exóticos" (SONTAG, 2003, p.77), sob a ótica ocidental do colonizador, como entendemos ser o caso da imagem de Don McCullin, que mostra uma criança albina extremamente magra no Campo da Cruz Vermelha para vítimas da fome, em Biafra, em 1969, que segue a estética do horror (Figura 6). McCullin já fotografou campos de batalha e vítimas de fomee optou por tal estética para fazer campanha em favor da paz e da solidariedade. Mas, em 1988, passou a clicar "as paisagens inglesas, talvez para exorcizar os fantasmas dos horrores que fotografou" (SOUSA, 2004b, p.73).

Figura 6 - Biafra 1969

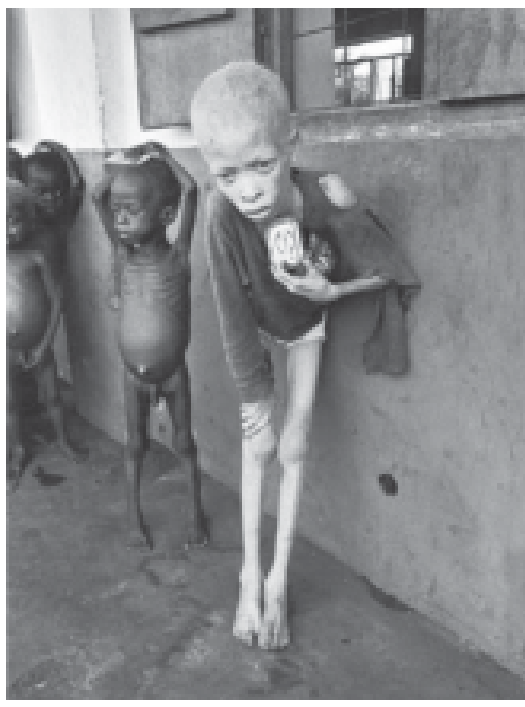

Fotografia: Don McCullin/Contact Press

Fonte: Biafra... (2014) 
O Código de Ética da National Press Photographers Association (NPPA) é mais específico que os anteriores, obviamente, por referir-se diretamente ao uso de imagens. A introdução do Código deixa claro que

\begin{abstract}
As imagens fotográficas e de vídeo podem revelar grandes verdades, mostrar o mal e o descuido, inspirar a esperança e o entendimento, e conectar as pessoas de nosso mundo pela linguagem visual. As fotografias também podem causar grandes danos se estão tomadas sem sensibilidade e respeito ou estão manipuladas.(NATIONAL PRESS PHOTOGRAPHERS ASSOCIATION, 2014) $)^{19}$
\end{abstract}

Entre as recomendações do Código da NPPA, está o dever de ser preciso e compreensivo na representação dos sujeitos; evitar estereótipos de grupos ou pessoas; esforçar-se por ser discreto e humilde com os sujeitos e respeitar a integridade do momento fotografado. Todos esses princípios, se seguidos, contribuiriam para garantir o respeito à dignidade das pessoas que aparecem nas fotografias, principalmente, ressaltamos, em momentos de dor e sofrimento.

No que se refere à prática diária do fotojornalista, o item 4 é bastante específico, ao dizer que o profissional deve tratar todos os sujeitos com respeito e dignidade, dando consideração especial àqueles vulneráveis e tendo compaixão com vítimas de crimes e tragédias. E mais: "Intrometerse em momentos privados de luto somente quando o público tem uma necessidade justificável para ser testemunha", ${ }^{20}$

O que dizer, então, da imagem do soldado iraquiano carbonizado na cabine do caminhão, fotografado em 1991, por Ken Jarecke (Figura 7)? A fotografia não foi publicada nos EUA durante a Guerra do Golfo, mas na Europa gerou protestos por parte do público. Leitores do jornal The Observer, o primeiro britânico a publicar a imagem, "insurgiram-se contra sua inclusão, pois consideravam que a foto ultrapassava os 'limites do admissível"" (SOUSA, 2004a, p.209).

19 Versão original: "Las imágenes fotográficas y de video pueden revelar grandes verdades, mostrar el mal y el descuido, inspirar la esperanza y el entendimiento, y conectar a la gente de nuestro mundo por el lenguaje visual. Las fotografías también pueden causar grandes daños si están tomadas sin sensibilidad y respeto o están manipuladas".

${ }^{20}$ Versão original: "Entrometerse en momentos privados de luto solamente cuando el público tiene una necesidad justificable para ser testigo". 
Figura 7 - Shot of an incinerated Iraqi soldier

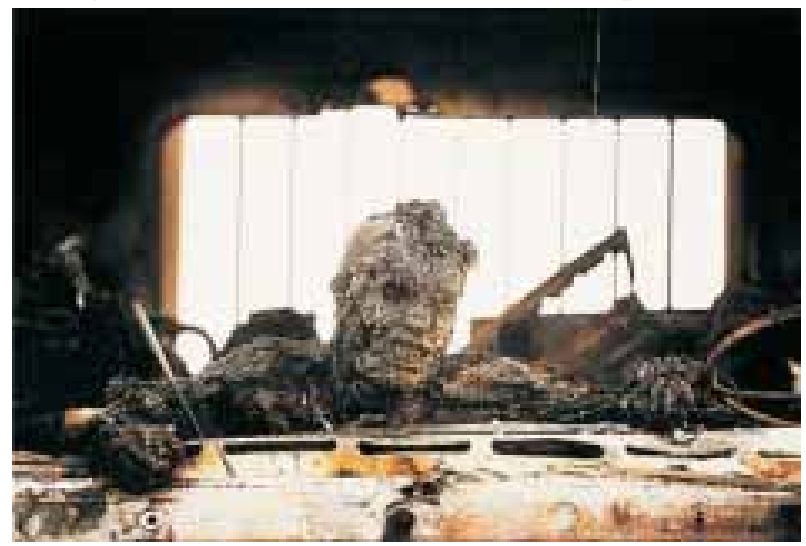

Fotografia: Ken Jarecke

Fonte: Picture...(2005)

Algo justificaria tal publicação? Que informação o público tem ao ver essa imagem, além de ter acesso a uma foto-choque? Tal fotografia, bem como a de corpos mutilados no meio de entulhos após explosão no metrô da Rússia em 2004, feita por Viktor Habarov, da agência Reuters (Figura 8), não estariam, então, de acordo com os princípios éticos apontados nos cinco códigos analisados.

Figura 8 - Explosão em metrô

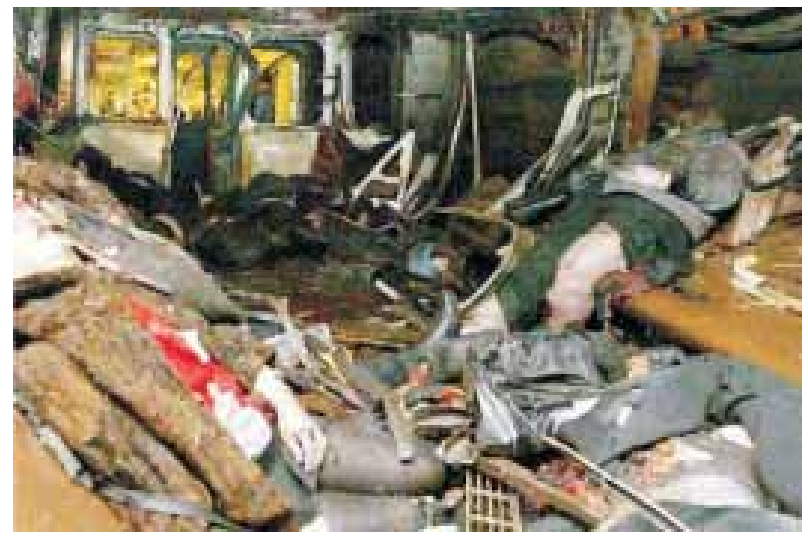

Fotografia: Viktor Habarov/Reuters

Fonte: Explosão...(2014) 


\section{Considerações finais}

Diante dos códigos e das imagens comentados neste trabalho, não nos cabe oferecer respostas, mas promover reflexões que contribuam para o exercício de um fotojornalismo mais ético, menos centrado no espetacular e mais voltado para a humanidade, uma vez que "o noticiável há de ser definido em relação com os valores democráticos e o cumprimento dos direitos humanos" (GONZÁLVEZ, 2004a, p.85). ${ }^{21}$

No jornalismo, a temática da violência e das grandes tragédias da humanidade sempre esteve presente, acompanhando, por conseguinte, $o$ nascimento e o desenvolvimento do fotojornalismo. Eo debate sobre quais informações são de interesse público também. Por isso, torna-se fundamental questionar: no âmbito da fotografia, que imagens devem chegar ao público? A autocensura dos profissionais de imprensa prejudicaria o direito de todos à informação?

Essas e outras perguntas continuam sem respostas definitivas após a conclusão deste estudo. Ao acompanharmos a evolução do fotojornalismo, a importância da cobertura de guerra (portanto, de violência) para a consolidação da atividade, o papel dos fotodocumentaristas na denúncia e nas transformações sociais, percebese que a discussão proposta aqui é apenas o começo de uma reflexão que deve acompanhar sempre os profissionais de imprensa e a produção acadêmica sobre o tema. Pois, no âmago de tal reflexão, encontra-se o debate sobre a ética, enfim sobre os limites da liberdade de expressão e do direito à informação.

Os cinco códigos apresentados neste trabalho encontram-se em sintonia no que se refere ao respeito à dignidade humana. Mas a verificação cuidadosa de cada um deles deixa claro também a necessidade de haver códigos específicos para o fotojornalismo, como o modelo apresentado por San Martin (1996), que inclui deveres, direitos e responsabilidades

${ }_{21}$ Versão original: "lo noticiable há de ser definido en relación com los valores democráticos y el cumplimiento de los derechos humanos". 
do fotojornalista, bem como do público para com esses profissionais. Pois, apesar da tomada de consciência dos profissionais e de organismos nacionais e internacionais da necessidade de códigos de ética e deontologia, não se tem dedicado espaço ao tratamento e controle do uso de imagens informativas, como se observa ao verificar detalhadamente os documentos selecionados. Apenas um deles, elaborado por uma associação de fotógrafos, aborda especificamente o fotojornalismo.

Apesar de parecer utópico, acreditamos, como Gozálvez (2004b, p.229), que é preciso e possível buscar respeito e qualidade na produção midiática, que virtudes como "espírito plural, inteligência cordial, desejo prudente e sereno de justiça, humanismo laico, respeito à igual dignidade das pessoas, solidariedade" podem "se enraizar e se desdobrar". ${ }^{22}$

Este trabalho, portanto, contribui para fomentar as discussões no campo dos limites éticos do uso das imagens, principalmente quando retratam dor e sofrimento, mas abre caminho para novos debates, como a manipulação das imagens possibilitada pelo avanço tecnológico, o que poderá ser tratado em textos futuros.

\section{Referências}

BALADA em Abu Ghraib. Veja Online, São Paulo, n. 854, 19 maio 2004. Disponível em: <http://veja.abril.com.br/190504/p_076.html〉. Acesso em: 12 abr. 2014.

\section{BARCELOS, Janaina Dias. Dor e sofrimento no fotojornalismo:} estudo de caso do world Press Photo of the Year 1955-2008. 2009. Dissertação (Mestrado em Comunicação e Jornalismo) - Faculdade de Letras, Universidade de Coimbra, Coimbra, Portugal, 2009.

22 Versão original: "espíritu plural, inteligência cordial, deseo prudente y sereno de justicia, humanismo laico, respeto a la igual dignidad de las personas, solidaridad" podem "arraigar y desplegarse". 
BIAFRA 1969. The digital journalist. Disponível em: <http:// digitaljournalist.org/issue0309//m03.html>. Acesso em: 12 abr. 2014.

CADÁVER de um dos filhos de Saddam Hussein. BBC News. Disponível em: <http://news.bbc.co.uk/2/shared/spl/hi/pop_ups/03/ middle_east_pictures_of_saddam0s_sons_(warning0_graphic_content)/ html/2.stm>. Acesso em: 12 abr. 2014.

CAMPS, Victoria. Opinión pública, liberdad de expresión y derecho a la información. In: CONILL, Jesus; GOZÁLVEZ, Vicent. Ética de los médios: uma apuesta por uma ciudadania audiovisual. Barcelona: Gedisa, 2004. p. 33-49.

CORNU, Daniel. Jornalismo e verdade: para uma ética da informação. Lisboa: Instituto Piaget, 1994.

DECLARATION of the rights and duties of journalists. Munique, 1971. Disponível em: <http://www.hirondelle.org/wp-content/uploads/2011/ 07/Declaration-of-The-Rights-and-Duties-Of-Journalists-Charter-ofMunich-1971.pdf >. Acesso em abr. 2014.

EXPLOSÃO em metrô. Folha do São Paulo. Disponível em: <http:// www1.folha.uol.com.br/folha/galeria/album/p_20040206-moscou08.shtml >. Acesso em: 12 abr. 2014.

\section{FEDERAÇÃO NACIONAL DOS JORNALISTAS. Código de ética} dos jornalistas brasileiros. Vitória, 2007. Disponível em: <http:// www.fenaj.org.br/federacao/cometica/codigo_de_etica_dos_j ornalistas_brasileiros.pdf >. Acesso em abr. 2014.

FIRE escape collapse. Stanley Forman photos. Disponível em: <http:/ /stanleyformanphotos.com/galleryfireescape.html>. Acesso em: $12 \mathrm{abr}$. 2014. 
GOZÁLVEZ, Vicent. Los relatos del mundo: entre la objetividad y la imparcialidad. In: CONILL, Jesus; GOZÁLVEZ, Vicent. Ética de los médios: uma apuesta por uma ciudadania audiovisual. Barcelona: Gedisa, 2004a. p. 79-109.

. Análisis ético-comparativo de los médios. In: CONILL, Jesus; GOZÁLVEZ, Vicent. Ética de los médios: uma apuesta por uma ciudadania audiovisual. Barcelona: Gedisa, 2004b. p. 187-232.

INTERNATIONAL principles of professional ethics in journalism. Paris: Consultative Club of International and Regional Organizations of Journalists, 1993. Disponível em: <http://ethicnet.uta.fi/international/ international_principles_of_professional_ethics_in_journalism>. Acesso em: abr. 2014.

MOTHER and son.. World Press Phot. 2004. Disponível em: <www.worldpressphoto.org>. Acesso em: 12 abr. 2014.

NATIONAL PRESS PHOTOGRAPHERS ASSOCIATION. NPPA: code of ethics. Disponível em: <https://nppa.org/page/ 631>. Acesso em: abr. 2014.

PICTURE power: death of an Iraqi soldier. BBC News, 9 may 2005. Disponível em: 〈http://news.bbc.co.uk/2/hi/middle_east/4528745.stm>. Acesso em: 12 abr. 2014.

SAN MARTIN, Maria de los Angeles. Código ético y deontológico para la fotografia e imagen informativa. Madrid: Trigo Ediciones, 1996.

SINDICATO DOS JORNALISTAS. Código deontológico dos jornalistas. Lisboa, 1993. Disponível em: <http://www.jornalistas.eu/ ?n=24>. Acesso em: abr. 2014. 
SONTAG, Susan. Olhando o sofrimento dos outros. Algés: Gótica, 2003.

SOUZA, Jorge Pedro. Forças por trás da câmara: uma perspectiva sobre a história do fotojornalismo das origens até o final do século XX. Coimbra: Minerva, 2004b.

SOUZA, Jorge Pedro. Uma história crítica do fotojornalismo ocidental. Chapecó: Argos, 2004a.

SUDAN: Famine victim in a feeding center. Miko.photo. 1993. Disponível em: <http://www.jamesnachtwey.com >. Acesso em: 12 abr. 2014.

TRAQUINA, Nelson. A tribo jornalística: uma comunidade transnacional. Lisboa: Editorial Notícias, 2004. 